\title{
3. \\ SPLITSKA MEĐURATNA LIKOVNA \\ SCENA IZMEĐU MODERNIZMA I \\ ANTIMODERNIZMA
}

\section{Ana Šeparović i Frano Dulibić}

\author{
UDK: 7.036(497.5 Split)“191/194“ \\ Izvorni znanstveni članak
}

Sažetak: U međuratnom razdoblju unutar splitske likovne scene postojale su raznovrsne tendencije. Uz dominirajući umjereni modernizam, posebna pozornost posvećena je vrlo izraženoj antimodernističkoj tendenciji. Ona je u to vrijeme predstavljala važnu komponentu u europskoj i hrvatskoj likovnoj produkciji. Kako likovni umjetnici tako i likovna kritika gotovo su ujedinjeni u neprihvaćanju avangardnih likovnih kretanja, a umjereni modernizam se u splitskoj sredini razvija u snažnom suglasju s tradicijom. Među splitskim kritičarima izdvaja se Ivo Delalle, koji kao jedan od pionira prihvaćanja Croceove estetike u nas, $s$ bitno više razumijevanja piše o europskoj likovnoj suvremenosti, osobito o kubizmu i o ekspresionizmu. U splitskom međuratnom slikarstvu prepoznaju se karakteristike antimodernizma u Vidovićevu djelu prožetom melankolijom, nostalgijom i patinom vremena, Jobovim ekstatičnim scenama punima mediteranske životne dinamike, slikama kao metaforama nostalgije i pohvalama moru Bonaccija Čika, Paraćevu i Tolićevu bijegu u idealizirani zavičaj, kao i u djelu Meneghellovih. Na području grafičkoga dizajna i karikature u djelima Radovana Tommasea, Ive Tijardovića i Angjela Uvodića rađenima u duhu art décoa zamijećeni su vrhunski dosezi. Kiparski kompleks splitske likovne scene razmatran je između prepoznavanja iskonskoga primitivizma forme Petra Smajića i senzibiliteta za klasične oblike djela Dujma Penića, najkompetentnije izraženoga u prikazu Vladana Desnice. ${ }^{1}$

Ključne riječi: splitski likovni modernizam, antimodernizam, likovna kritika, slikarstvo, grafički dizajn, karikatura, kiparstvo, Vladan Desnica

$\int$ akon Prvog svjetskog rata, pod dojmom velikog uništenja, u filozofiji i kulturi prevladala je odbojnost prema tehnologiji te općenito znanosti i pozitivizmu, što se odrazilo u intenzivnoj kritici modernoga napretka, ali i pojavi raznih oblika bijega od stvarnosti, koja se sada percipirala prijetećom i pogubnom. Na filozofskom i estetičkom obzoru prevladale su antiintelektualne i antipozitivističke ideje Nietzschea, Bergsona i Crocea, ideje koje daju prednost duši i intuiciji nad razumom i znanosti. U umjetničkoj praksi progre-

1 Ovaj rad sufinancirala je Hrvatska zaklada za znanost projektom br. 4153 Croatia and Central Europe: Art and Politics in the Late Modern Period (1780-1945). 
sivni avangardni eksperimenti i ideje o spajanju znanosti i umjetnosti, osobito futuristička i konstruktivistička fascinacija tehnologijom polako ustupaju mjesto likovnim idiomima koji teže „povratku redu“. Umjetnici se okreću stilskim izrazima temeljenima na realističkome vokabularu: de Chiricova Pittura metafisica i Picassov neoklasicizam samo su neki od karakterističnih primjera. Istovremeno, tematski se orijentiraju idealizaciji svijeta oko sebe, nerijetko oblikujući nestvarne tematske komplekse bazirane na mitologiji, povijesti i religiji, takozvane „protusvjetove“. Na taj način, bježeći u bolja prošla ili nepostojeća utopijska vremena, zapravo reagiraju na surovu stvarnost svakodnevice. Upravo taj segment modernističke umjetnosti u kojem je snažno izražena kritika modernoga doba i progresa, a čiju glavnu odrednicu zapravo čini prisustvo protusvjetova oblikovanih u „protustilovima“ (kako smo nazvali taj naoko regresivni moment vraćanja svojevrsnome realizmu) nazivamo antimodernizmom. Tu zapravo modernističku tendenciju dosad prepoznatu u književnosti, ${ }^{2}$ filozofiji i ideologiji te izdvojenu kao značajnu odrednicu hrvatske likovne umjetnosti prve polovine 20. stoljeća, ${ }^{3}$ u ovome radu nastojat ćemo predstaviti kao ravnopravnu, čak prevladavajuću tendenciju na splitskoj međuratnoj likovnoj sceni. $S$ obzirom da je fokus ovog istraživanja usmjeren na razumijevanje antimodernističke komponente u različitim opusima, dokumentacija i interpretacija različitih tendencija odredila je količinu prostora posvećenog pojedinom stvaraocu, a ne njegov značaj i likovna kvaliteta. Stoga, ako je ponešto manji prostor posvećen najvećim imenima poput Emanuela Vidovića i Ivana Meštrovića, to ni u kojem slučaju ne znači umanjivanje njihove važnosti. Neupitno je da njihova djela predstavljaju nedvojbene vrhove onodobne hrvatske likovne produkcije.

U likovnim umjetnostima antimodernizam se promatra kao skup određenih umjetničkih pojava koje se očituju prije svega u tematskom izboru, odnosno u izboru motiva, a potom i u načinu slikanja. Antimodernizam ne bi bilo dobro shvatiti kao regresivnu tendenciju koja „vraća vrijeme unatrag“, naprotiv. U svjetlu ideje Zorana Kravara, koji ističe da je antimodernizam zapravo protutendencija, vidimo da antimodernizam ne bi mogao nastati bez modernizma, da proizlazi iz modernizma i da traži načine da se izrazi drugačije od avangardnih tendencija, pritom odražavajući duh svoga vremena. Antimodernizam je svjetonazorska tendencija koja iskazuje odbojnost prema suvremenim tehnološkim dostignućima pod pretpostavkom da suvremena civilizacija razara moralna načela koja društvo čine stabilnim. Stoga na slikama antimodernista gotovo nikad ne nalazimo tvornice, automobile ili svjetla velegrada, oni su zaokupljeni krajolicima s netaknutom prirodom i idealiziranim aktovima, a motivi su im određeni pogledom u utopijske svjetove. Osim toga, likovni umjetnici koji su težili stvoriti način izražavanja s prepoznatljivim nacionalnim

\footnotetext{
Temu antimodernizma u književnosti iscrpno je obradio Zoran Kravar. Usp. Zoran Kravar, Antimodernizam, Zagreb 2003. i Isti, Svjetonazorski separei, Zagreb 2005.

3 Prvi je Kravar povezao termin antimodernizam s likovnom umjetnošću, i to na djelu Ivana Meštrovića i Mirka Račkog. Usp. Zoran Kravar, „Vidovdanski protusvjetovi i Matoševi protutekstovi“, 15 dana, 47/2004., br. 4-5, 8-15. Potom je Zidić povezao Kravarev antimodernizam s djelom Vjekoslava Paraća. Usp. Igor Zidić, Vjekoslav Parać, Zagreb 2010., 24. Širi prikaz hrvatskoga likovnog antimodernizma, s posebnim osvrtom na opuse Meštrovića, Miše, Kljakovića, Babića i Plančića donesen je u radu: Ana ŠEparović - Frano Dulibić, „Nekoliko primjera antimodernizma u hrvatskoj likovnoj umjetnosti“, Radovi instituta za povijest umjetnosti, 37/2013., 199-210.
} 
obilježjima bili su protiv pukog prenošenja inozemnih avangardnih tendencija i birali su motive s tradicijskim obilježjima hrvatske i europske kulture.

U međuratno vrijeme hrvatsku likovnu umjetnost temeljno određuje prevlast umjerenog modernizma Proljetnoga salona, Grupe nezavisnih, Grupe trojice i Udruženja umjetnika Zemlja, među kojima se tematski najviše izdvajaju dvije vrste odnosa prema stvarnosti. Jedni prikazuju grubu realnost suvremenog urbanog života, s naglaskom na noćnom životu, kao i težak život u ruralnim područjima (Gecan, Uzelac i Trepše, pripadnici Udruženja umjetnika Zemlja), a drugi stvaraju prizore idealiziranih prostora netaknutih tehnološkim napretkom, poput čiste prirode, sela i sl. (Nezavisni i Grupa trojice). Pritom je likovna scena izražajnostilski homogena u dominantnome realističkom vokabularu: od neoklasicističkog i magičnog realizma 1920-ih do kolorizma i socijalnog realizma 1930ih godina. Stoga možemo zaključiti da hrvatskim likovnim međuraćem dominira umjereni modernizam $s$ izraženom antimodernističkom tendencijom te sporadičnim avangardnim pojavama poput Zenita, koje nisu bile dužega vijeka ni šireg utjecaja.

\section{KARAKTERISTIKE SPLITSKE MEĐURATNE LIKOVNE SCENE}

Nakon Prvoga svjetskog rata Split ima oko 22000 stanovnika. To je vrijeme kada većinu čine stanovnici predgrađa, uglavnom ruralno stanovništvo. Duško Kečkemet, najplodniji istraživač i poznavalac splitske kulturne scene, nalazi da je tijekom 19. stoljeća kulturnu scenu stvarala građanska klasa, dok su dominantnu ulogu u prvoj polovici dvadesetog stoljeća, preuzela „školovana djeca težačkih pučana“, i to ne samo u kulturnom, nego i političkom životu grada. ${ }^{4}$ To je dovelo do stanovitih pomaka: oslabio je utjecaj talijanske, a ojačao utjecaj njemačke kulture do 1918. godine, odnosno do raspada Austro-Ugarske, dok se istodobno odvijalo i okretanje francuskom kulturnom krugu, posebice u likovnim umjetnostima, koje je trajalo sve do Drugoga svjetskog rata, praćeno francuskim kapitalom uloženim u splitsku industriju. Ti utjecaji nisu se širili samo putem boravaka pojedinaca u tim zemljama, nego često i preko časopisa i drugih publikacija tada dostupnih. Ujedno, s povećanim postotkom pismenog stanovništva, rastao je i broj novina i časopisa koji su izlazili u Splitu, a tridesetih godina objavljivano ih je čak dvadeset. U to vrijeme Split ima oko 35000 stanovnika te u njemu djeluje dvadesetak likovnih umjetnika, koji su organizirali čak 130 izložbi. ${ }^{5}$ Izložbe održane u Salonu Galić predstavljale su splitskoj javnosti važne segmente likovne produkcije.

Nije splitska likovna scena iznimka u svojoj suzdržanosti prema modernome u slikarstvu i umjetnosti općenito - tako je bilo i u Zagrebu - ali zaboravlja se da je slično stanje i na europskoj sceni, gdje su oduvijek grupice umjetnika ili izdvojeni pojedinci predstavljali avangardnu manjinu u odnosu na većinu koja je više ili manje slijedila tradicijske vrijedno-

Duško Kečkemet, Likovna umjetnost u Splitu 1900 -1940., Split 2011., 10.

5 Isto, 29-35. 
sti. Glavnina umjetnika nastojala je elemente modernosti povezati s tradicijskim nasljeđem, a rijetki su bili oni koji su išli za radikalnim raskidanjem s tradicijom.

Razumjeti stvaralačke intencije međuratne splitske likovne scene možemo upravo kroz dihotomiju moderno-antimoderno. To, ustvari, pretpostavlja tumačenje odnosa prema avangardnim stremljenima kao pravog modernizma, na jednoj strani, te umjereno modernističkih tendencija, uključujući antimodernizam, na drugoj. U ovome radu neće biti moguće protumačiti sve autore splitske likovne scene, no kroz primjere raznorodnih opusa moguće je vidjeti i razumjeti raznovrsne silnice i kontekst koji je bitno odredio splitsku međuratnu likovnu scenu. Nju su oblikovali umjetnici koje možemo svrstati u tri skupine. U prvoj treba istaknuti umjetnike koji djeluju u Splitu poput Silvija Bonaccija Čika, Emanuela Vidovića, Angjela Uvodića, Vjekoslava Paraća, Petra Bibića, Ivana Mirkovića, Antuna Zuppe i Milana Tolića. Za njih se može reći da djeluju u sjeni druge, manje grupe umjetnika koju čine velikani hrvatske umjetnosti, porijeklom iz Splita ili okolice, poput Ivana Meštrovića, Marina Tartaglije, Jerolima Miše i Joze Kljakovića. Oni zapravo žive u većim centrima poput Zagreba i Beograda, istovremeno zadržavajući snažnu vezu sa Splitom, povremeno u njemu djelujući i izlažući, ali i prikazujući splitske, odnosno dalmatinske motive u svojim djelima. Treću skupinu čine umjetnici iz drugih dijelova Hrvatske, Jugoslavije ili čak Europe, koji gostuju na izložbama u Splitu, među kojima vrijedi izdvojiti izložbe beogradske „Lade“ i skupine „Oblik“. Među gostujućim izložbama gotovo vrijedi pravilo da u Splitu izlažu umjetnici koji su se bavili dalmatinskim pejzažom, što je vjerojatno razlog zainteresiranosti lokalne zajednice, ali i kritike i publike (Petar Dobrović, Stojan Aralica, Slavko Tomerlin; kao kuriozitet izdvajamo činjenicu da su više samostalnih izložbi održali ruski emigrant Ipolit Danilovič Majkovski i šibenski slikar Pavle Popović).

Promatrajući splitsku likovnu scenu unutar šireg konteksta hrvatske umjetnosti i hrvatskih likovnih grupacija, odmah upada u oči činjenica da najjača međuratna likovna institucija Proljetni salon, iako je održala izložbe u brojnim hrvatskim i jugoslavenskim gradovima (osim u Zagrebu izložbe su organizirali čak triput u Osijeku, potom Beogradu, Novom Sadu, Subotici i Somboru), niti jednu izložbu nije organizirala u Splitu, a isto vrijedi i za Udruženje umjetnika Zemlja. Od skupnih još vrijedi izdvojiti Jadransku izložbu 1925. godine, čime smo iscrpili gotovo sve skupne izložbe održane u Splitu tijekom tih dvadesetak međuratnih godina. ${ }^{6}$ No ipak, u tom razdoblju održan je priličan broj samostalnih izložbi u Splitu, pri čemu većina u spomenutom salonu Galić, ${ }^{7}$ a posebno važnu i veliku cjelinu čine izložbe karikature, na kojima osobito dolazi do izražaja humor, odnosno satirički duh splitskih umjetnika. ${ }^{8}$

Glavne značajke, ali i osnovnu problematiku splitske likovne scene najpreciznije je definirao Tin Ujević. On probleme prepoznaje u odvojenosti mladih splitskih umjetnika od velikih umjetničkih centara i njihovom strogo lokalnom djelovanju, kao i pomanjkanju likovnih udruženja i izostanku volje za zajedničkim nastupanjima i djelovanjem:

\footnotetext{
O splitskim izložbama opširno u: Nevenka Bezıć, Likovne izložbe Splita 1885-1945, Split 1962.

Više o važnosti Galićeva salona u: D. KečKemet, Likovna umjetnost u Splitu, 36-41.

8 Više o splitskom krugu karikaturista u: Frano Dulibić, Povijest karikature u Hrvatskoj do 1940. godine, Zagreb 2009., 255-306.
} 
Svakako bi za obavještenje javnosti trebalo nešto napisati o skupini mladih radnika koja živi u Splitu, skoro odvojena od svijeta i poslije svršetka studija potpuno utovljena u oblasni zaborav. Ima slabo medjusobnoga dodira, nikakvoga društvenoga sijela i odnosa, a još manje zajedničkoga Vjeruju. Nema nešto što bi se moglo nazvati splitska škola, jer svaki gleda na svoju stranu. Govorilo se da će se osnovati umjetnički klub, ali do toga nije došlo zbog novčanih poteškoća. Za Dalmaciju, zemlju kakvih takvih umjetničkih tradicija, nije utješno ovo stanje umjetničke dezorganizovanosti.

U Ujevićevim riječima može se naslutiti i implicitno prepoznavanje antimodernizma kao glavne odrednice splitskog likovnog međuraća, upravo zbog temeljne orijentacije zavičajnom, povijesnom i mitskom:

U Dalmaciji koja još živi u svom srednjevekovnom licu, nerazvijenost trgovine i industrije čuva Arisku krv i oskudicom željeznica upućuje ljude na more (...) Ako proizvodnja žita ne može da podmiri godišnje potrebe stanovništva, zato aromatično bilje kao ružmarin, kadulja, lovorika i ruža laska čulima mladih esteta i budi u njima želju za dokonom sanjarijom u fantastičnim dragama. Dubljina mora kraj obale, zatoni i zalivi kao i mnogobrojna ostrva odomaćuju neizmernost vode i objašnjuju nam tugu harfiste Tristana kao i čežnju ukletoga Holandeza. ${ }^{10}$

Zamjećuje i usporene odjeke novih avangardnih strujanja („A onaj pokret evropske umjetnosti kroz zadnju četvrt stoljeća, zvali ga Fauves, kubizam, futurizam, neoklasicizam, ekspresionizam ili nadrealizam ovamo se nije žurio ni da stigne" $)^{11}$ te oprez umjetnika pri pristupanju modernijem izrazu, ali i konzervativni ukus publike: „Splitski umjetnici, i kada su učili kod modernih, suviše su bojažljivi kao afirmacija vremena. Boje li se konzervativnosti publike, buržujskog ukusa u gradu gdje je teško naći i modele?"12

\section{SPLITSKA LIKOVNA KRITIKA}

Među čak pedesetak imena splitske likovne kritike bilo je vrlo malo onih koji su doista stručno pisali. Duško Kečkemet smatra da ih je bilo svega desetak, ${ }^{13}$ a netko bi stroži vjerojatno tu brojku još umanjio. Iz gotovo svakog teksta izvire zaziranje od avangardnih pravaca koje kritičari smatraju europskim „pomodnostima“. Preferiraju se razne vrste realizama uključujući impresionizam, a više od analize stila kritičari poklanjaju pažnju motivima, među kojima se ponajviše cijene motivi sa zavičajnim obilježjima. Među književnicima koji su objavljivali likovne kritike izdvaja se Tin Ujević, među umjetnicima Jerolim Miše, a od ostalih autora vrijedi istaknuti Ivu Delallea, Ćiru Čičin Šaina, Vladimira Rismonda, Ivu Lahmana i Vinka Brajevića. ${ }^{14}$

\footnotetext{
9 Tin Ujević, „Umjetnički Split. Šef ukusa Galić“, Jadranska pošta (Split), br. 107, 9. 5. 1930., 7.

10 Isti, Rosandić, Zagreb 1920., 6-7.

11 Isti, „Dvije izložbe“, Jadranska pošta (Split), br. 110, 13. 5. 1930., 7.

12 Isti, „Umjetnički Split“, 7.

13 D. KeČKemet, Likovna umjetnost u Splitu, 185.

14 Više o splitskoj likovnoj kritici vidjeti u poglavlju „Likovna kritika u Splitu“ u: Isto, 185-189.
} 
Splitski kritičari u umjetnikovoj zavičajnosti i lokalnoj tradiciji pronalaze glavna uporišta i trajno određenje njegova djela, nerijetko na slikama tragajući za znakovima koji upućuju na dalmatinsko podrijetlo autora, što se pak najsnažnije osjeća u tekstovima Ćire Čičin Šaina koji ističe kako je

(...) jedna zdrava parola, koja je Rusiji i Slavenstvu dala najpotpuniji izraz za umjetnost: počva, počveništvo, upućivanje sebe na svoju zemlju, duboko prodiranje u svoju rasu, to, kao sadržaj i cilj, to, kao duh koji ispunjava umjetničku dušu, stvara osebujan sensibilitet, to, od čega nam je svima priroda, atavizam, vaspitanje, život, sredina, sve oko nas i u nama, dalo jedan naročiti sadržaj i cilj. ${ }^{15}$

Zgroženost suvremenim, osobito avangardnim tendencijama predstavlja drugu nezaobilaznu odrednicu koja je snažno obilježila tadašnju splitsku likovnu kritiku. O futurizmu, kubizmu i dadaizmu pisao je Branislav Radica:

Današnje slikarstvo futurista, kubista, dadaista i svih ostalih ekstremista je pomodno slikarstvo, koje će možda doprinijeti kakvu česticu budućem slikarskom shvaćanju, ali će ono samo za sebe biti sigurno uvršteno u historiji slikarstva pod naslovom: dekadensa 20. tog vijeka. ${ }^{16}$

Nije rijedak slučaj da kritičari za „pomodnost“ i „ekstremnost“ novih strujanja nalaze krivca upravo u tehnološkome napretku civilizacije:

Ova bezidejna epoha kojoj imamo čast pripadati rađa, po riječima Tina Ujevića takove konvulzivne genije, koji će radije obijati blagajne prije nego li se posvete danas nadasve diskreditiranom poslu oko pridizanja duševnosti, onoga što je umrlo u zaglušnoj buci mašinerije, u oblacima olovnatog dima tvornica. ${ }^{17}$

Među splitskim kritičarima izdvaja se Ivo Delalle, jedan od pionira prihvaćanja Croceove estetike u nas, ${ }^{18}$ koji 1918. godine u Hrvatskoj prosvjeti piše opsežan članak pod nazivom „Benedetto Croce“, ističući intuiciju kao glavni umjetnički pokretač i važnost izraza kao konkretne realizacije ${ }^{19}$ te s bitno više razumijevanja piše o europskoj likovnoj suvremenosti, osobito kubizmu i ekspresionizmu:

Reakcija protiv mesnatih boja, iskrivljenih linija, bolesnog romanticizma, tih elemenata umjetnosti same impresije bio je kubizam. Čudan i neshvatljiv, kolikogod hoćete, ali je bio potreban (...) Kubizam se povraća na praizvore umjetnosti, na vječne zakone prostora, mjere, voluma, opsega i težine (...) Teži za apstraktnim, za apsolutnim (...) Kubizam se divi pračovjeku, djetinjskoj jednostavnosti, onom čovjeku, koji je čedan i siromašan, ali znade gledati prirodu iskreno i spiritualno (...) Ekspresionizam (...) gleda u prirodi nešto apsolutnoga, religioznoga i mističnoga. „Per visibilia ad invisibilia“. Vidi ne ono što je prolazno, transitorno i sensibilno, već tako zvanu „res aeterna“. ${ }^{20}$

15 Ćiro Čıčın ŠAIn, „Slikar Parać“, Novo doba (Split), br. 236, 26. 9. 1929., 5.

16 Branislav RadicA, „Slikarstvo i priroda“, Hrvatska riječ (Split), br. 139, 4. 10. 1924., 6.

17 Miljenko BukARICA „Umjetnici našega vremena“, Hrvatska riječ (Split), br. 139, 4. 10. 1924., 5.

18 Više o ranoj recepciji Croceove estetike u Hrvatskoj u: Zlatko PosAvac, „Rana recepcija estetike Benedetta Crocea u Hrvatskoj“, Filozofska istraživanja, 13/1993., br. 3, 675-684; Katarina Hraste, „Benedetto Croce, mi i drugi“, Mogućnosti, 48/2001., br. 4-6, 25-45.

19 Ivo Delalle, „Benedetto Croce“, Hrvatska prosvjeta, 5/1918., br. 2, 13-16.

20 Isti, „Jerolim Miše“, Novo doba (Split), br. 144, 23. 6. 1923., 2-3. 
Konzervativnost splitske kritike možda je najsnažnije došla do izražaja u recepciji djela Marina Tartaglije izloženih na izložbi Medulića 1919. godine. ${ }^{21}$ Tartaglijina djela Bog hermafrodit i Maneken, s oznakama talijanske avangarde, izazvala su popriličnu konsternaciju među samim umjetnicima i kritičarima, a vjerojatno još snažniju među publikom. Vinko Kisić njegove slike naziva „nastranima“,22 a Nedjeljku Subotiću su „odvratne“ i predlaže „da se ta umjetnička nedonoščad nauče crtati i prodrijeti u narav svijetla i boja, a onda neka se zanašaju za pojedinim umjetničkim pravcima, ili - ako su geniji - neka traže svoje putove “. ${ }^{23}$ Zbog iznimnoga nerazumijevanja koje je splitska likovna scena pokazala prema njegovim djelima, Tartaglia u članku pod nazivom „Vademecum posjetiocima izložbe“ nastoji obrazložiti svoja likovnoestetska polazišta. U tekstu veliča čistoću i autonomiju umjetnosti te njezinu potpunu oslobođenost od oponašanja prirode i izazivanja emocija, jer se ona u tom slučaju ne razlikuje od „pornografije“. Poistovjećujući umjetnost s igrom, naziva ju „nevinom fikcijom, velikom obmanom i velikim zabavljačem reda duhovnoga“ te ističe kako će nas ona „riješiti spona svagdanjeg života i prenijeti u više sfere velikog zabavljača“. ${ }^{24}$

\section{SPLITSKO MEĐURATNO SLIKARSTVO - ZAOKUPLJENOST ZAVIČAJEM I TRADICIJOM}

Među splitskim slikarima na prvom mjestu treba spomenuti djelo Emanuela Vidovića, koje Igor Zidić ispravno svodi na borbu dvaju načela: realističkog i simbolističkog. ${ }^{25}$ U izgradnji svog likovnog izraza, Vidović je doista otišao do krajnjih granica u razgradnji vidljive stvarnosti kako bi joj podario simboličku snagu, emociju, ugođaj i u tome je bio daleko hrabriji, snažniji i moderniji od ostalih sudionika onodobne splitske likovne scene. $S$ druge strane, tematikom je njegov opus orijentiran ponajviše prema sutonskim pejzažima te interijerima kuća i crkvi. Njegovo djelo uvelike je prožeto melankolijom, nostalgijom i patinom vremena, što sve predstavlja obilježja antimodernizma. U ogromnom opusu teško bi bilo pronaći sliku na kojoj se jasno vide obilježja suvremene arhitekture, modernog broda ili bilo kojeg obilježja onodobne suvremene tehnologije, odnosno, bilo koji motiv koji bi izravno povezivao promatrača s vremenom u kojem je slika nastala. Vidović je slikao slojeve prošlosti, gustoću zraka i zaustavljeno vrijeme. Ne samo tematski, nego i načinom slikanja često se vraća u ranija vremena. No specifične, profinjene nijanse umirujućih ugođaja koji je prenosio u svojim najboljim djelima zapanjuje i današnje promatrače, te je lako zaključiti da je svojom specifičnom antimodernističkom komponentom dao nezaobilazan prinos hrvatskomu modernizmu. Njegovu duševnost i prevlast intuicije nad razumom prepoznao je i Ivo Delalle:

21 O recepciji djela Marina Tartaglije na toj izložbi više u: Sandi Bulımbašić, Društvo hrvatskih umjetnika „Medulic“", doktorska disertacija, Filozofski fakultet u Zagrebu, 2014., 363-368, 374-375.

22 Vinko Kisıć, „S umjetničke izložbe“, Novo doba (Split), br. 80, 12. 4. 1919., 2.

23 Nedjeljko Suвотіс́, „Jugoslavenska umjetnička izložba u Splitu“, Hrvatska prosvjeta, 6/1919., br. 5-6, 124.

24 Marin Tartaglia, „Vademecum posjetiocima izložbe“, Jadran (Split), br. 49, 9. 4. 1919., 2.

25 Igor ZIDIĆ, „Emanuel Vidović: Rana polarizacija za potonju sintezu“, Emanuel Vidović, Rovinj 2002., 3. 
Kad pobijedi logika intuicije i plohe, Vidovićeve slike bit će simboli najfinijih čuvstava, zajedničkih svakoj vrsti umjetnosti već kodificiranih u najmodernijoj Bergsonovoj filozofiji. Osloboditi se od ropskih lanaca sirovine, to neka bude program Vidoviću za budućnost. ${ }^{26}$

Sasvim drugu vrstu antimodernističkoga bijega u svojim je djelima utjelovio Ignjat Job. Na slikama iz 1920ih u duhu magičnoga realizma ostvaruje „apoteozu mitskog doživljaja i idealizaciju svijeta Mediterana kao Arkadije“, ${ }^{27}$ dok se 1930-ih okreće prizorima iz malih dalmatinskih mjesta, izražene i potencirane životne dinamike (luđaci, tučnjave, plesovi i proslave, procesije) s likovno jasnim uporištima u Van Goghu i reminiscencijama na slikarstvo Pietera Bruegela st. Riječ je o ekstatičnim grupnim scenama nabijenima emocijom i životnom energijom, koje možemo opisati kao vizualizacije nietzscheovskoga dionizijevskog Rauscha, stvaralačke i životne opijenosti, iz čega nedvojbeno izrasta njegov tzv. „spontani“ koloristički ekspresionizam. Niko Bartulović zamjećuje kako Job „gleda na prirodu ekstazom i daje je u ekstazi“, ${ }^{28}$ dok Čičin Šain ističe kako su „njegove ekstaze čovjeka i umjetnika bile stanje u kome je stvarao, kao sveta rodilja, kao mistička majka. Job je ličnost, jedna od rijetkih ličnosti u našemu današnjemu stvaranju (...) koja je (...) sasvim dalmatinska“, ${ }^{29}$ a Lahman u njegovim jarkim svjetlosnim efektima prepoznaje „pravu i sigurnu boju naših dalmatinskih vidika“"30

Dok je Ivan Mirković (1893. - 1988.) kao kipar cijelo vrijeme ostao blizak realističkom izrazu, kao slikar je već prije odlaska na akademiju u Pragu počeo simplificirati ljudsku figuru stilizacijom ju približavajući primitivističkom izrazu već dvadesetih godina (uz kraći izlet u magični realizam oko 1930.). Taj ekspresivni primitivizam od tridesetih na dalje postaje njegov prepoznatljiv izraz, svoj poseban intenzitet doživljavajući šezdesetih godina dvadesetog stoljeća. ${ }^{31}$ Veliki broj slika s ribarima koji krpaju mreže, jedu, piju ili razgovaraju, ribarima čiji težak život je izražen u grubim formama, bez suvišnih detalja izraz je koji bilježi zaustavljeno vrijeme, tradiciju koju vezuje uz iskonsko ishodište: kao da je tako bilo oduvijek i to se nikad neće promijeniti, bez obzira na to što svi znaju, pa i slikar, da je svijet već odavno drugačiji. I krajolici su netaknuta priroda, a kada je riječ o arhitekturi kamenih dalmatinskih kuća, one su potpuno „urasle“ u prirodu. Mirković nije bio usamljen u svojem priklanjanju primitivnim oblicima. Ne samo da je to vidljivo kod ranije spomenutog Ignjata Joba, nego i kod Antuna Zuppe.

U slikarskom opusu Silvija Bonaccija Čika, istaknutoga, no s vremenom marginaliziranog predstavnika splitske likovne scene, prepoznajemo dvije osnovne tematske razine simbolističku i maritimnu, od kojih obje nose snažan antimodernistički pečat. Njegova su

\footnotetext{
26 Ivo Delalle, „Umjetnici s mora“, Jadran (Split), br. 52, 12. 4. 1919., 2.

27 Ivanka Reberski, Realizmi dvadesetih godina i hrvatsko slikarstvo, Zagreb 1994., 46.

28 Niko Bartulović, „Sa otvorenja Jobove izložbe“, Novo doba (Split), br. 162, 1. 7. 1929., 4.

29 Ć[iro] Č[IČIn] Š[AIN], „Pred posmrtnu izložbu Ignjata Joba“, Novo doba (Split), br. 156, 8. 7. 1937., 5.

30 Ivo Lahman, „Ljetna izložba Ignjata Joba“, Novo doba (Split), br. 163, 2. 7. 1929., 2 i 7.

31 Ivan Mirković počeo je izlagati vrlo rano, još 1913. godine, a na akademiju u Prag odlazi 1919. godine. To je razdoblje kada traži svoj izaz i često ga mijenja. I u skulpturi se može pratiti kako do 1918. do sredine tridesetih polazeći od realističkog dolazi do primitivističkog, te se potom ponovo vraća realističnom izrazu. Naravno, Mirković je i vrstan karikaturist, kako u crtežu tako i u skulpturi. Više o Mirkovićevu opusu u katalogu retrospektivne izložbe: Iris SLADE, Ivan Mirković, Split 2005., 1-13.
} 
djela metafore nostalgije (slika Nostalgija, 1924.) odnosno pohvale glavnom simbolu zavičaja - moru. Ivo Delalle piše kako

(...) on prati našeg ribara u tihim jutrima i sumornim predvečerjima po dragama i uvalama oko Kašuna, Sustjepana i Baluna u najrazličitijim zemanima bilo po maestralu, neveri, jugovini bilo po strašnom nevremenu lebiča, kad ribari moraju održati najveću borbu sa valovima is elementima razjarene prirode. ${ }^{32}$

Objašnjavajući vlastito stvaralaštvo, Čiko osobito naglašava sjećanje na djetinjstvo i zavičaj kao glavna polazišta, ali i činjenicu da mu je slikanje idealiziranih krajolika služilo kao bijeg od čemerne svakodnevice:

Ja sam na pr. svoje marine sa prve izložbe u Sarajevu radio ne po naravi, nego po sjećanju. Vadio sam ih, kao vojnik za vrijeme rata, iz svoje nostalgije za djetinjskim vedrim životom kod kuće, kad sam, mjesto mirisa kasarna i bolnica, udisao slanost mora. Ja sam tada hotimice bježao od tmurnosti ondašnjeg života prikazujući ono njegovo drugo naličje: vedrinu i ljepotu. ${ }^{33}$

Istovremeno se grozi suvremenih pojava na europskoj likovnoj sceni, ističući intuiciju kao ispravan put u likovnome stvaralaštvu:

Današnja umjetnost boluje od aberacija. U tim forsiranim formama i strujama jasno se zrcale razne socijalne struje i pojave, koje muče današnje bolesno društvo (...) $U$ toj praznini i duševnoj ukočenosti mogu da se stvaraju samo fantastične, nejasne, konfuzne, forsirane, stvari za koje je teško i tumača naći a kamo li ih osjetiti. One su apsolutna negacija pravilnog osjećanja i intuiranja, pa djeluju kao aborti mozgova u dementnom stanju. ${ }^{34}$

Vjekoslav Parać gotovo može poslužiti kao paradigmatski primjer splitskog likovnog međuraća. Sadržajno vezan uz rodni kraj, slikao je krajolike iz Solina i Kaštela, ribare i težake, život i dalmatinsku svakodnevicu, toj motivici ostajući vjeran cijeloga života. Kritika je naglašavala mediteransku komponentu, odnosno uronjenost Paraćeve umjetnosti u njegovoj zavičajnosti, preciznije salonitanskoj antičkoj tradiciji, ${ }^{35}$ na njegovim slikama prepoznajući da ih je slikao „pravi Primorac, Dalmatinac“36 te je s ponosom isticala činjenicu kako je napustio Pariz iz ljubavi prema Dalmaciji: „Ali, zasićen Parizom, virtuozizmom metropole međunarodne kozmopolitske umjetnosti, osjetio je potrebu, skoro i fizičku, da ponovo dođe u živ dodir sa svojom zemljom, kršom u dalmatinskom primorju. ${ }^{\text {“37 }} \mathrm{Sam} \mathrm{Pa}$ rać o iskustvu Pariza ovako govori:

32 [Ivo] D[elalle], „Čiko“, Novo doba (Split), br. 220, 21. 9. 1924., 2.

33 Pero ŠEgota, „Jedan posjet Čikinom atelijeru“, Novo doba (Split), br. 273, 23. 11. 1927., 2.

34 Silvije Bonacci Čıко, Katalog III. kolektivne izložbe slikara Čika (S. Bonacci), Split 1928., 5-6.

35 „Solinski pejzaž (...) do siromaštva određen u jasnoći svojih kardinalnih konstruktivnih momenata, a s druge strane, bogat lokalnim vibracijama zemlje i mora kao malo gdje u Dalmaciji, urezao se je kao duboka brazda u vizuelnu misao slikara Paraća.“ Usp. Vladimir Rismondo, „Izložba Vjekoslava Paraća“, Novo doba (Split), br. 301, 25. 12. 1936., 33.

36 Ivo Lahman, „Izložba Vjekoslava Parača“, Novo doba (Split), br. 242, 3. 10. 1929., 5.

37 Ćiro Čıčın Š AIN, „Dalmatinski slikar koji je napustio Pariz da se vrati u Dalmaciju“, Novo doba (Split), br. 82, 7. 4. 1934., 9 . 
Trube svi mogući i nemogući „izmi“, pa koji vrag da radi. Čovjek se oduševljava, čudi, postaje skeptik, misli o čemu je vrijedno i nevrijedno misliti (...) Kubističke i purističke konstrukcije Picassa, Ozenfona nijesu me oduševljavale, kao ni apstraktno slikarstvo ala Joan Miro, Picabia i njima sličnim. Napisane ideje o tim djelima čestoput su mnogo interesantnije od samih djela. ${ }^{38}$

U pismu iz Pariza, upućenom Vladanu Desnici, Parać (kojeg je Desnica i financijski pomagao) žali se na suvremen način života u Parizu: „(...) boulevardski plakati zasjenjuju slikarstvo. No u eri smo toga. Plakata, šlagera i rekorda. Sve neka brzina koja je postala sebi svrhom. “39 Prvo poglavlje monografije o Vjekoslavu Paraću pod naslovom „Škola, podrijetlo, izvori“ Igor Zidić započinje podnaslovom kojim je nepogrešivo odredio Paraćev karakter i svjetonazor presudan za njegov likovni izraz: „Usađeni sentimenti i stečeno znanje. Upoznavanje svijeta i čuvanje zavičajnog. Inklinacija tradiciji: moderni konzervativac“. 40 Paraćev antimodernizam Zidić je vidio upravo u konzervativnom karakteru koji u potpunosti prenosi u djelo:

Njegov antimodernizam ne prihvaća i ne nosi masku avangardne stilistike, nego je cjelovito antimoderan: kako u tematskom (sadržajnom) tako i u stilskom (morfološkom) smislu. Koje nam sadržaje, naime, posreduju Paraćeve alegorijske i povijesne slike; koje sentimente? Nedvojbeno je da središte njegove boli ispunja osjećaj tragičnog gubitka humaniteta, koji je - u neka davna vremena, u neko sretno „zlatno doba“ - još bio živ. ${ }^{41}$

Kao izrazit primjer antimodernizma splitske međuratne scene izdvaja se i djelo Milana Tolića, čiji se karakter djelovanja sažima u frazi kako je u „stalnom dosluhu s tradicijom, a u raskoraku sa suvremenošću“. Pišući o njemu, Vinko Srhoj zaključuje da se tradicionalizam „tijekom godina pretočio u konzervativnost, dok je intimizam zatvorene sredine $\mathrm{u}$ kojoj je živio sve više poprimao stagnantne obrise provincijalizma“ ${ }^{42}$ Odnos prema tradiciji i antičkom nasljeđu Tolić je svojedobno izrazio i svojim neslaganjem s idejom postavljanja Meštrovićeva Grgura Ninskog na Peristil. To je rezultiralo poznatom karikaturom (za koju se zaboravilo da joj je autor Milan Tolić) na kojoj don Frane Bulić tjera Grgura Ninskog s Peristila. ${ }^{43}$

Veliki Tolićev prijatelj bio je Mate Meneghello Rodić, čije likovne kvalitete na malom broju sačuvanih slika i fresaka nisu zanemarive, no zbog neistraženosti i rasutosti opusa, on i dalje ostaje bez svog važnog mjesta na splitskoj, ali i hrvatskoj likovnoj sceni. ${ }^{44}$ Njegovo slikarstvo izraženih neoklasicističkih značajki srodno je s Kljakovićevim čvrstim i monumentalnim likovima u pejsažu koji najčešće predstavlja idiličan svijet.

38 Juraj Ivanko, „Slikar Vjekoslav Parač, Jadranski dnevnik (Split), br. 19, 12. 4. 1934., 3.

39 Vjekoslav Parać - Vladanu Desnici, Pariz, 30. ožujka 1931., Osobna ostavština Vladana Desnice, kut. Prepiska do 1945. I. Zahvaljujemo profesoru Dragi Roksandiću na uvidu u Paraćeva pisma Desnici.

40 I. Zidić, Vjekoslav Parać, 7.

41 Isto, 24.

42 Vinko SRHOJ, „Stagnantni okvir zavičajnosti“, Slobodna Dalmacija (Split), br. 14449, 23. 2. 1991., 48-49.

43 Momčilo Popadić, „Devedeset godina? Kad prije“, Slobodna Dalmacija (Split), br. 13738, 26. 2. 1989., 14-15.

44 Iako je u Splitu imao zapažene izložbe karikatura, do sada nije objavljen niti jedan podatak gdje se nalaze njegove otisnute ili originalne karikature te stoga još uvijek nije moguće govoriti o njegovoj ulozi u povijesti karikature u Hrvatskoj. 
I kada je riječ o Virgilu Meneghellu Dinčiću možemo potvrditi izrazitu povezanost s tradicionalnim vrijednostima, slikanjem vjerskih i narodnih motiva. Još 1923. godine Ivo Delalle napisao je kako njegovo slikarstvo ne donosi ništa novo te da ima vještu tehniku ali „sa starim shvaćanjem“ “45 Iznimna zanimljivost, ali nedovoljna poznatost stvaralaštva Meneghellovih upućuje na potrebu istraživanja kako bi njihov doprinos bio adekvatno valoriziran.

\section{GRAFIČKO OBLIKOVANJE: OD SECESIJE DO ART DÉCOA}

Dok je prihvaćanje suvremenih likovnih tendencija u slikarstvu bilo opterećeno težnjom da se sačuvaju tradicionalne vrijednosti, u području grafičkog oblikovanja prihvaćanje novog, ili kako bi to tada rekli „pomodnog“, odvijalo se daleko lakše i rezultiralo iznimnim dostignućima na europskoj razini, posebice kod dvojice školskih kolega i prijatelja, Radovana Tommasea i Ive Tijardovića. ${ }^{46}$ Radilo se o novom, ali ne avangardnom pravcu, nego o u čitavom svijetu - općeprihvaćenom suvremenom načinu izražavanja, art décou.

Plakati Radovana Tommasea imaju korijene u secesijskom oblikovanju koje je preraslo u pročišćeniju varijantu art décoa. Iako mu je opus ostao nevelik zbog prerane smrti, kvaliteta radova je iznimna, pa nema pregleda hrvatske povijesti plakata u kojem on nije zastupljen. ${ }^{47}$ Ranije isticanim utjecajima Gustava Klimta i Egona Schielea treba dodati i dosad nezamijećen utjecaj minhenskog Simplicissimusa, znamenitog njemačkog časopisa s likovnim prilozima vrhunskih europskih karikaturista, na što izravno upućuje Tijardovićev dnevnik: „Prepirali smo se o velikim umjetnicima, o crtačima; on je bio za Gulbransona, a ja za Dudovicha u karikaturama Simplicissimusa“. 48 Za likovne stvaraoce koji su se posvetili grafičkom oblikovanju plakata, letaka, ilustracija, kao i grafičkog dizajna knjiga i novina, sasvim je razumljivo i opravdano njihove uzore nalaziti među istaknutim umjetnicima iz njihovog područja, a ne unutar europske slikarske elite. Ipak, vrijedi istaknuti kako likovna kvaliteta Tommaseovih radova ne proizlazi iz usvajanja crtačkih svojstava Olafa Gulbransonna ili nekog drugog autora, već iz pronalaženja i razvijanja vlastitih likovnih izražajnih mogućnosti.

Isto vrijedi i za Ivu Tijardovića koji je razvio sasvim drugačija izražajna sredstva. Njegovo preferiranje Dudovicheva izraza, kao i Tommaseovo Gulbransonnova, govori puno više o njihovim mladenačkim likovnim senzibilitetima, nego što upućuje na puko usvajanje ili variranje njihovih likovnih karakteristika. Promatranjem likovnih radova u bečkoj reviji Faun oko 1920. godine, uočavamo ne samo da se Tijardović uklopio, nego možemo bez pretjerivanja reći da je imao prepoznatljiv rukopis te izrazito čist i zanimljiv art décoovski izraz koji se svojom likovnom atraktivnošću isticao među stilovima drugih suradnika. ${ }^{49}$

45 Ivo Delalle, „Slike Meneghello-Dinčića“, Novo doba (Split), br. 231, 6. 10. 1923., 2.

46 Ivo Tijardović, „Sjećanje na život i vrijeme (6)“, Nedjeljna Dalmacija (Split), br. 652, 6. 11. $1983 ., 25$.

47 Lada Kavurić, Hrvatski plakat do 1940., Zagreb 1999., 102-105; Slavica Marković (ur.), Stoljeće hrvatskog plakata, Zagreb 2001., 42-43.

48 Duško Keč́nmet, Nepoznati Tijardović, Split 2012., 13.

49 U reviji Faun isticali su se svojim art décoovskim radovima: Paul Styx, Lily Singer, Oskar Franz, Imre V. Santo, Viktor Weixler. 
U svom slikarstvu Angjeo Uvodić ostao je zarobljen u vlastitoj varijanti postimpresionizma, $s$ čvrsto oblikovanim formama, a u motivima gotovo redovito vezan uz idealizirane krajolike. S druge strane, kao karikaturist, Uvodić je taj žanr doveo do rijetko dosegnutih visina na nacionalnoj razini, u Splitu stekavši iznimnu popularnost. Njegove kolorirane karikature iz međuratnog razdoblja, koje se čuvaju u Galeriji umjetnina u Splitu, trebale bi biti uvrštene u europske antologije portretne karikature. Gotovo nevjerojatno djeluje njegova podvojenost između konzervativne idealizirane klasičnosti u slikarstvu (koje usprkos tome nije bez kvaliteta) i potpuno slobodnog izražavanja u žanru karikature u kojem je na najbolji način spojio analizu fizičkih i karakternih osobina pojedinca s art décoovskom linijom, krajnjom plošnošću i apstrahiranjem detalja. ${ }^{50}$

\section{KipARSTVO IZMEĐU REALISTIČNOG KLASICIZMA I PRIMITIVIZMA}

O povezanosti Ivana Meštrovića i Splita i značaju te veze za njegov opus pisano je na mnogo mjesta i nema smisla ponavljati opće poznate činjenice. Za ovu je temu značajno da u međuratnom razdoblju (pogotovo od 1932. godine) Meštrović često boravi i radi u Splitu, gradu za koji ga vežu i rani mladenački dani kada je 1900. radio u radionici majstora Pavla Bilinića, gradu u kojem je bio impresioniran antičkom kulturom. Već u tim mladenačkim danima stvarala se podloga za Meštrovićev eklektični kiparski izraz u kojem su snažno prisutne komponente europske kiparske tradicije, posebice renesanse, kao i starih civilizacija. Meštrović je nedvojbeno izrazit primjer kiparskog izraza koji modernost traži kroz tradiciju, koji stvara svoj modernitet zadubljen u različite slojeve prošlosti, a tematski se krećući između dva protusvijeta: mitskog i religijskog. ${ }^{51}$

Iako kiparstvo u međuratnome Splitu egzistira u sjeni velikoga Meštrovića, ne može se reći da nije izrodilo iznimna i zanimljiva djela i autore. Kao zanimljivost splitske međuratne likovne scene svakako treba izdvojiti prepoznavanje jedne, prema tadašnjem shvaćanju, marginalne pojave - naivnoga kiparstva Petra Smajića. Priprosti seljak iz Poljica javlja se na samostalnoj izložbi 1934. godine djelima u kojima iskonskim primitivizmom forme, prispodobivim romaničkoj i ranokršćanskoj umjetnosti, u drvu oblikuje primordijalne teme, poput čovjeka, žene i konja te religijske motive nailazeći na sveopće razumijevanje tadašnje kritike i publike: „Umjetnost Petra Smajića stoga je čista, nevina, nekompromisna, bez ikakve kulturne primjese. Nije mu bilo potrebno da baca sa sebe balast naše civilizacije “. ${ }^{2}$ Kritika je isticala iskonsku povezanost s kulturnom tradicijom, zemljom, dovodeći čak Smajićevu pojavu u vezu sa suvremenim europskim primitivizmima, odnosno interesom za djela „primitivne“ afričke umjetnosti:

\footnotetext{
50 Reprezentativni primjeri pokazani su na izložbi Uvodićevih djela iz fundusa Galerije umjetnina u Splitu 2002. godine kat. br. 58-61. Usp. Iris Slade, Angjeo Uvodić, Split 2002., 48-49.

51 Iscrpnije o tumačenju Meštrovićeva, Kljakovićeva, Mišeova i Plančićeva antimodernizma u: Ana ŠEPARović - F. Dulibić, „Nekoliko primjera antimodernizma u hrvatskoj likovnoj umjetnosti“, 199-210.

52 S. V., „Sutra se kod Galića otvara izložba skulptora seljaka“, Novo doba (Split), br. 46, 23. 2. $1934 ., 5$.
} 


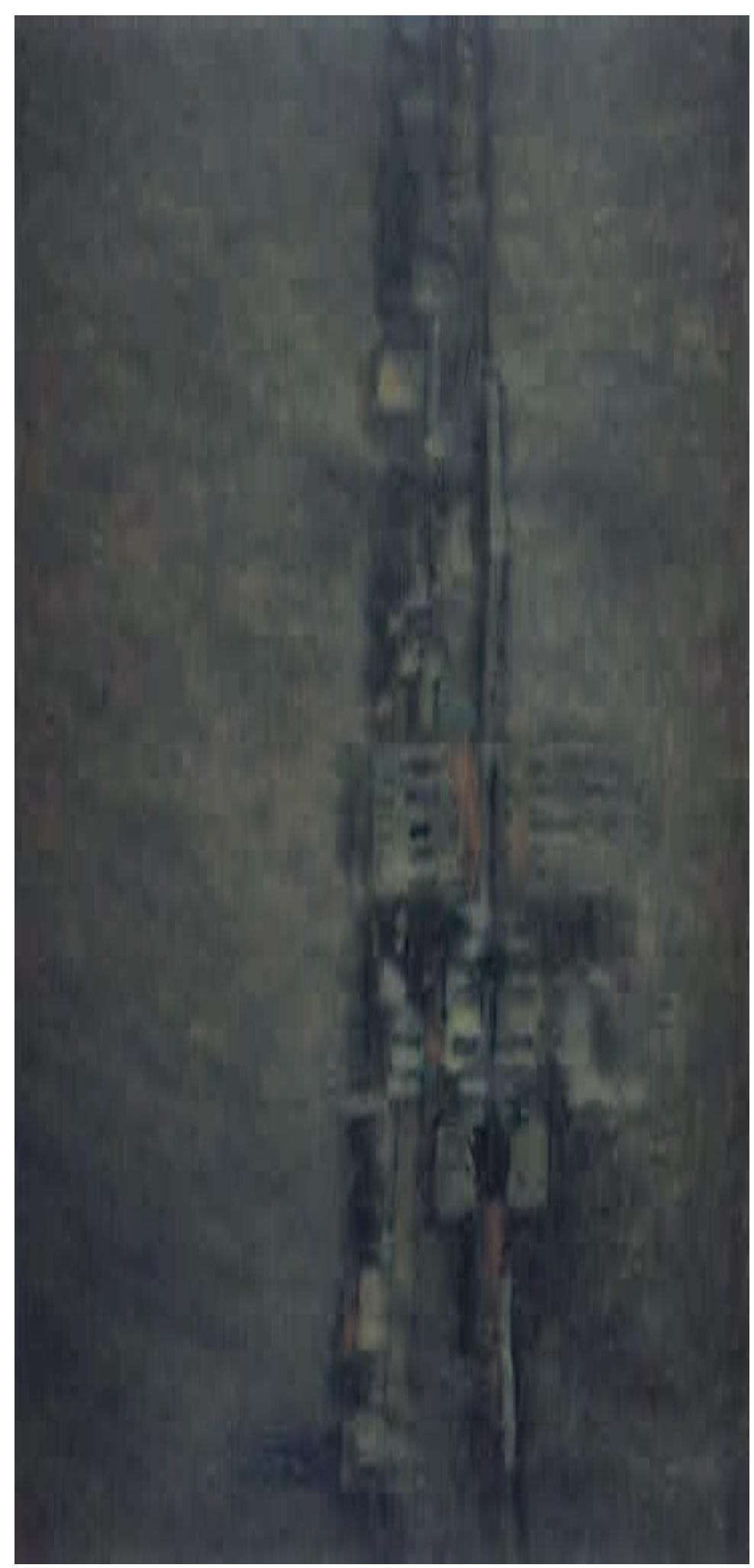

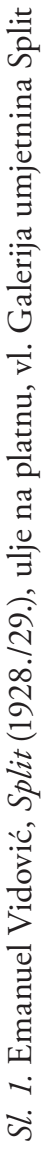




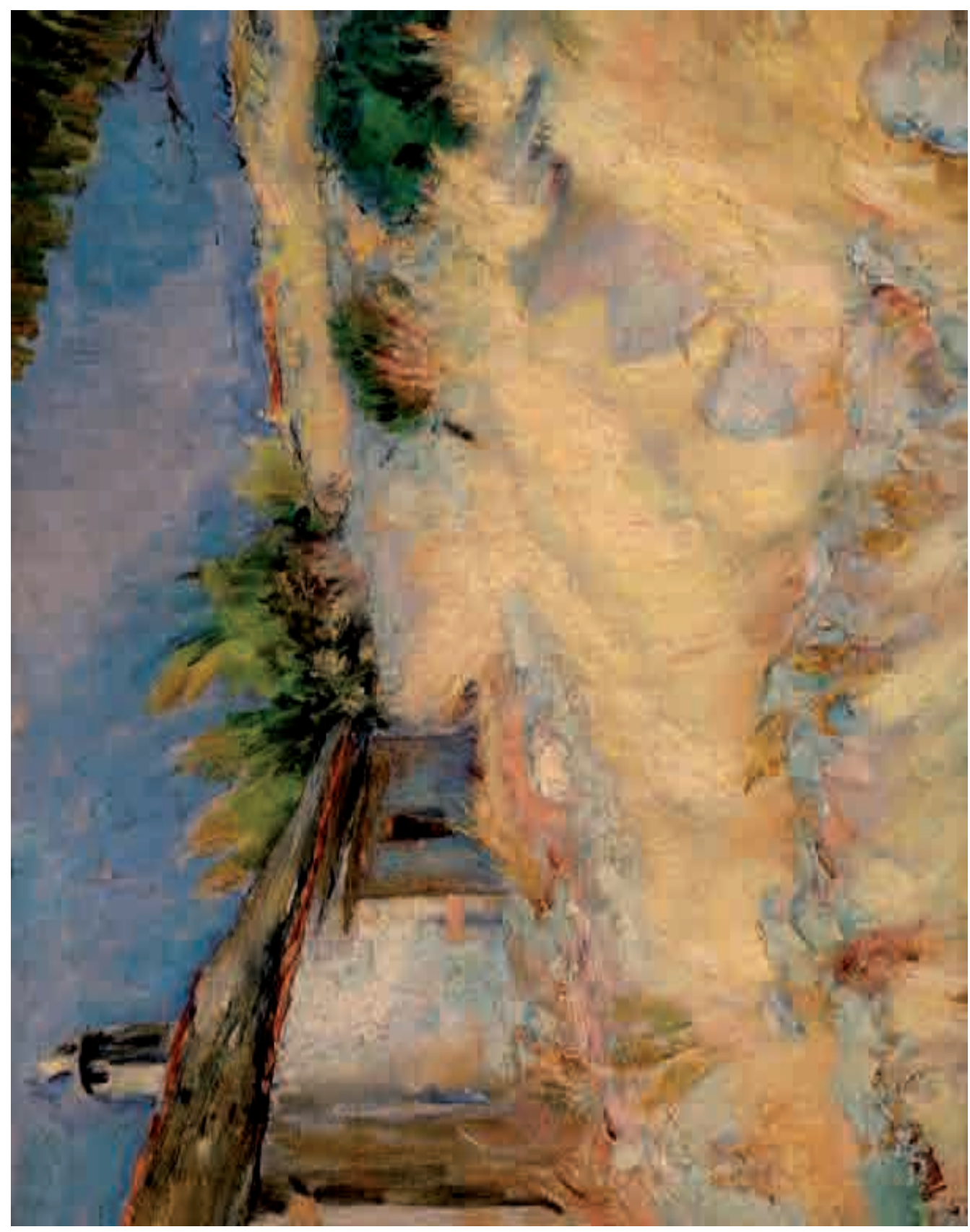

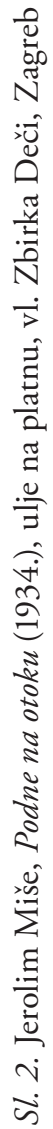




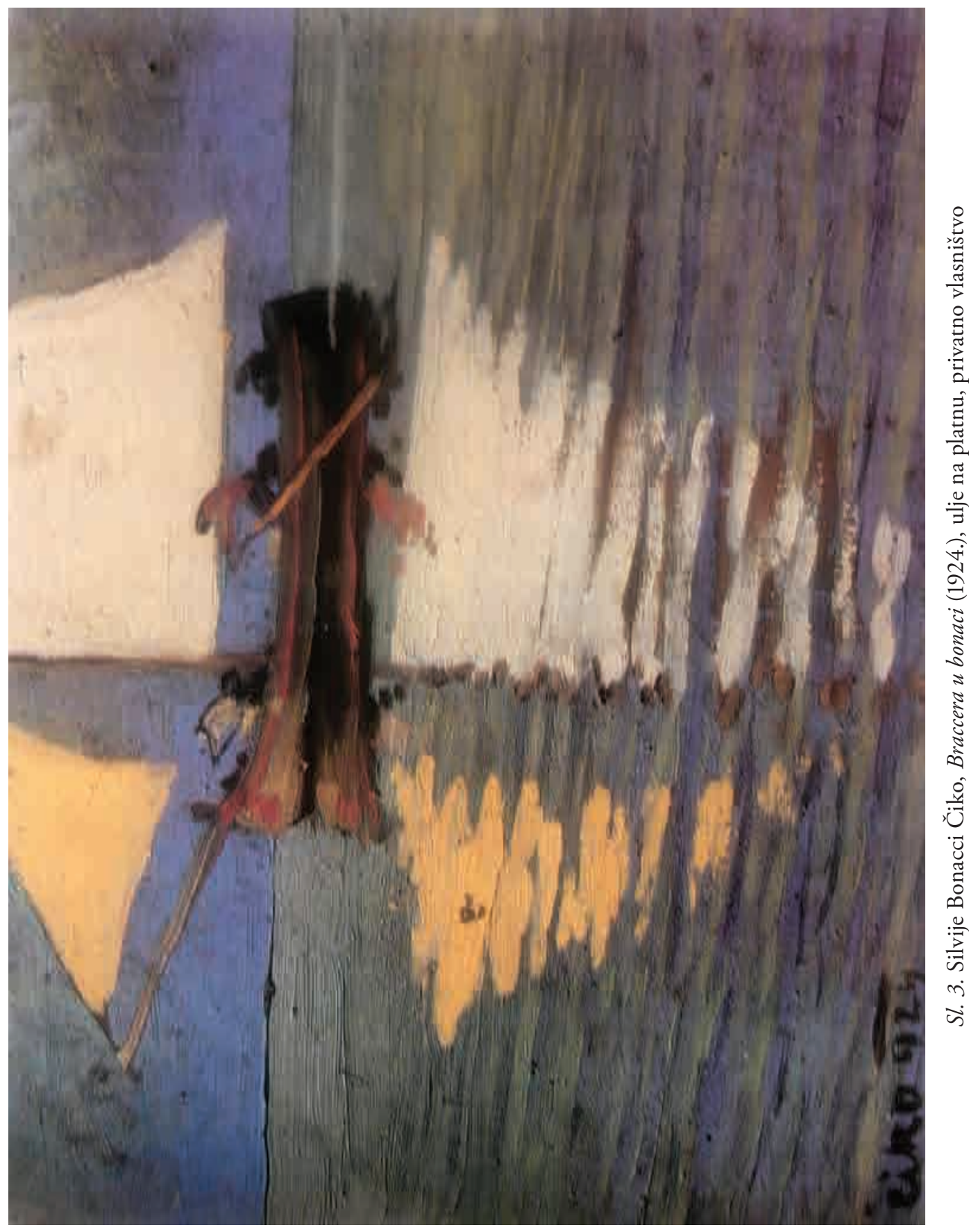




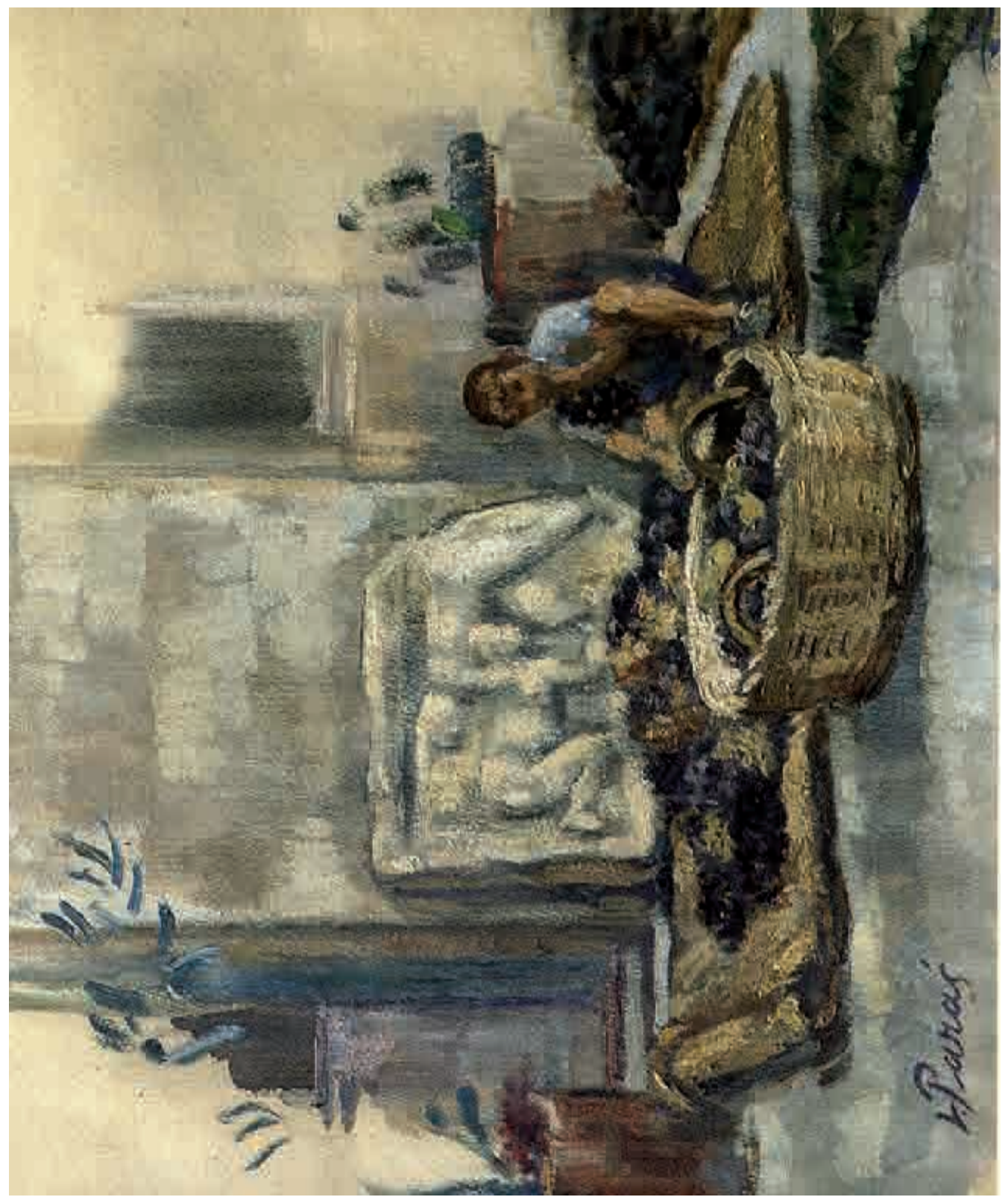

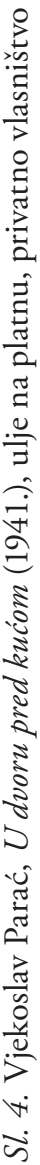




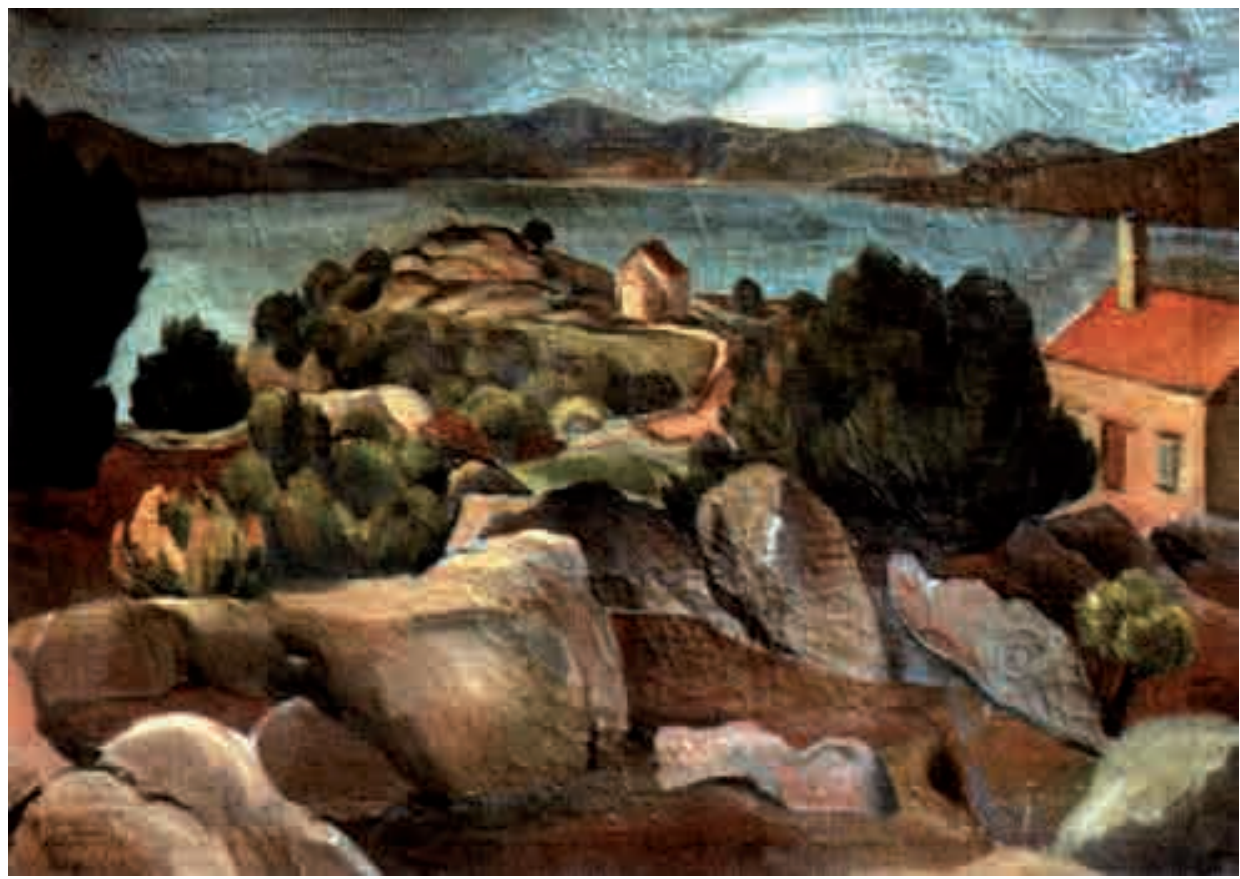

Sl. 5. Milan Tolić, Pejsaž (1930.), ulje na platnu, vl. Galerija umjetnina Split

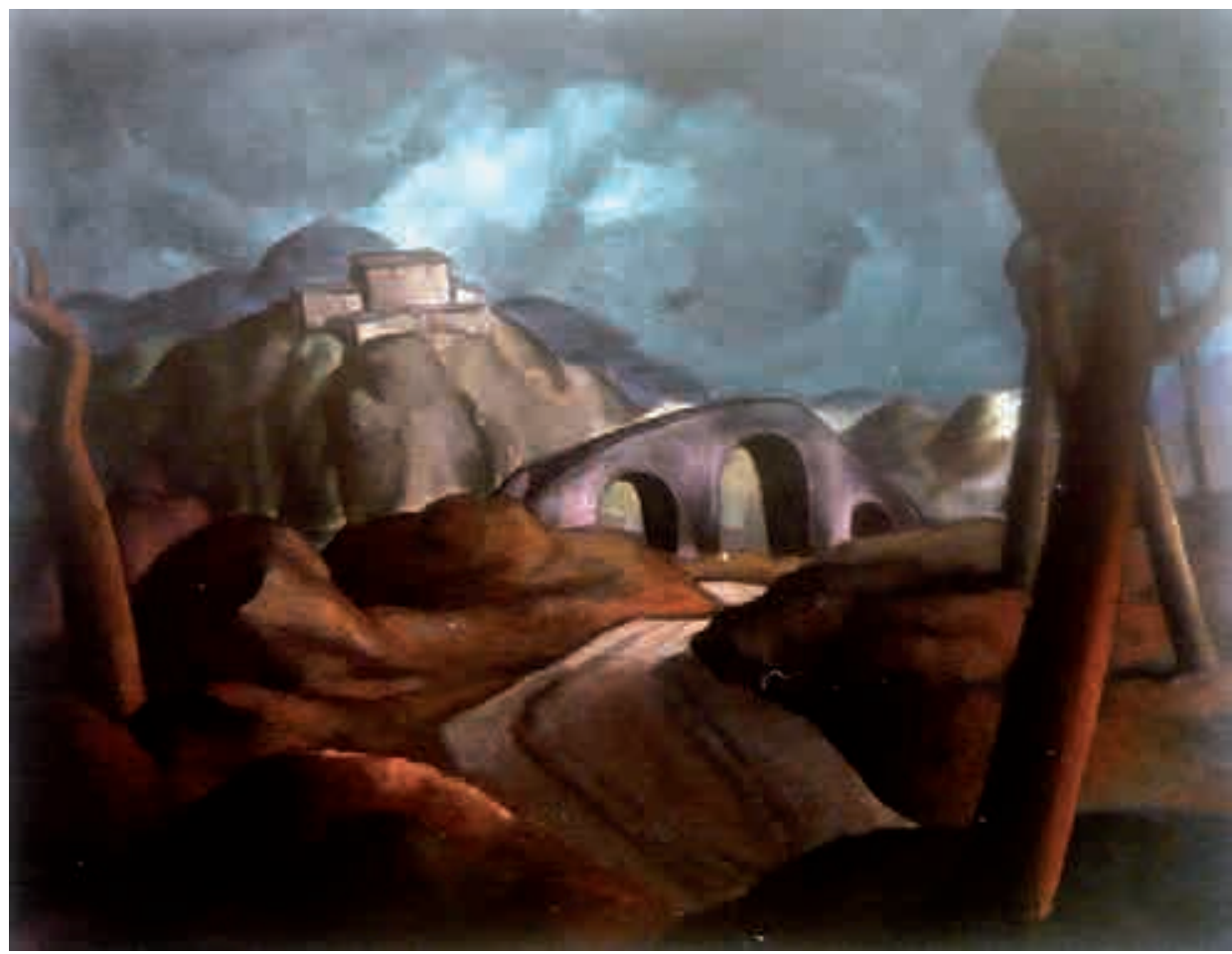

Sl. 6. Mate Meneghello Rodić, Pejsaž (1920.), ulje na platnu, vl. Galerija umjetnina Split 


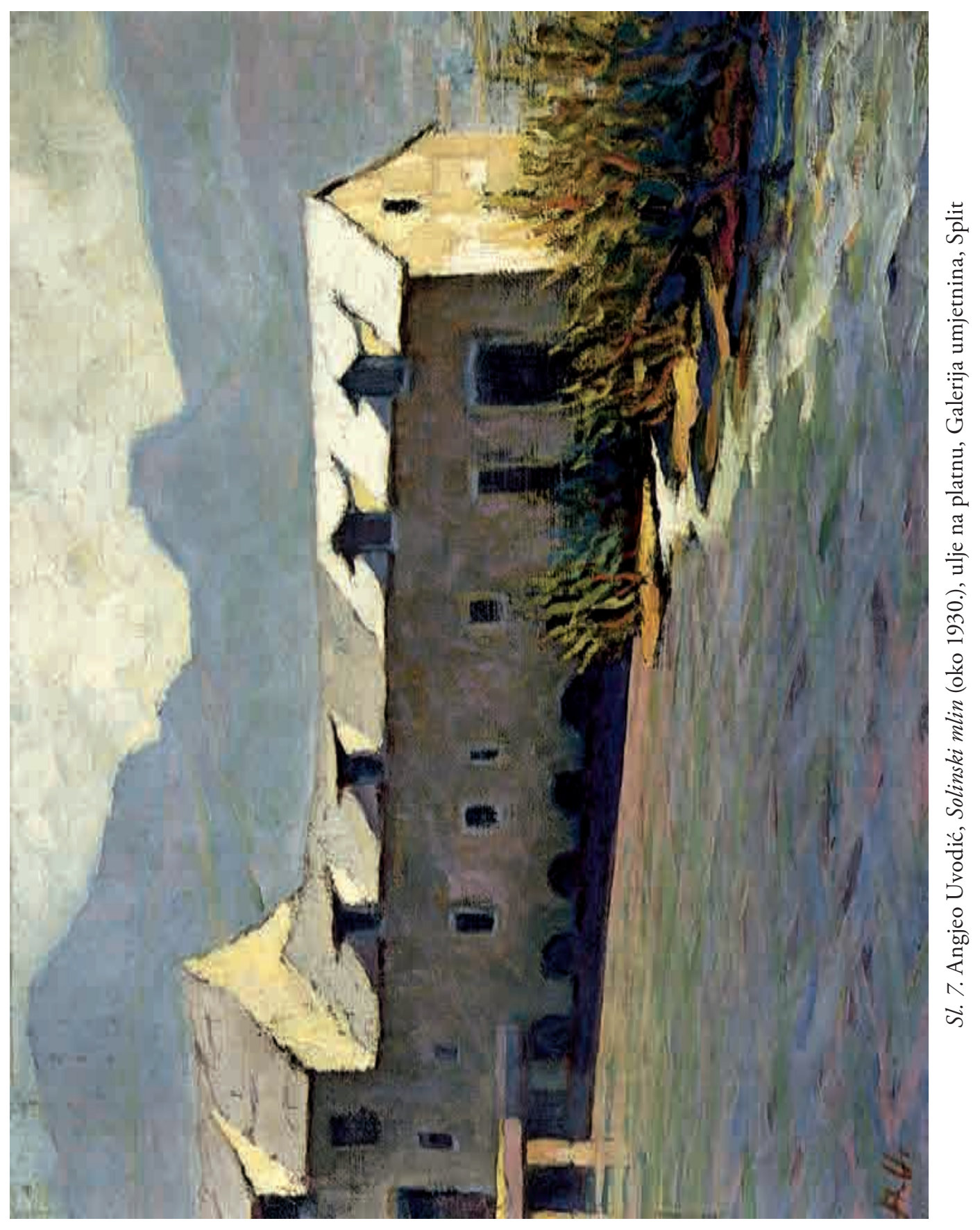




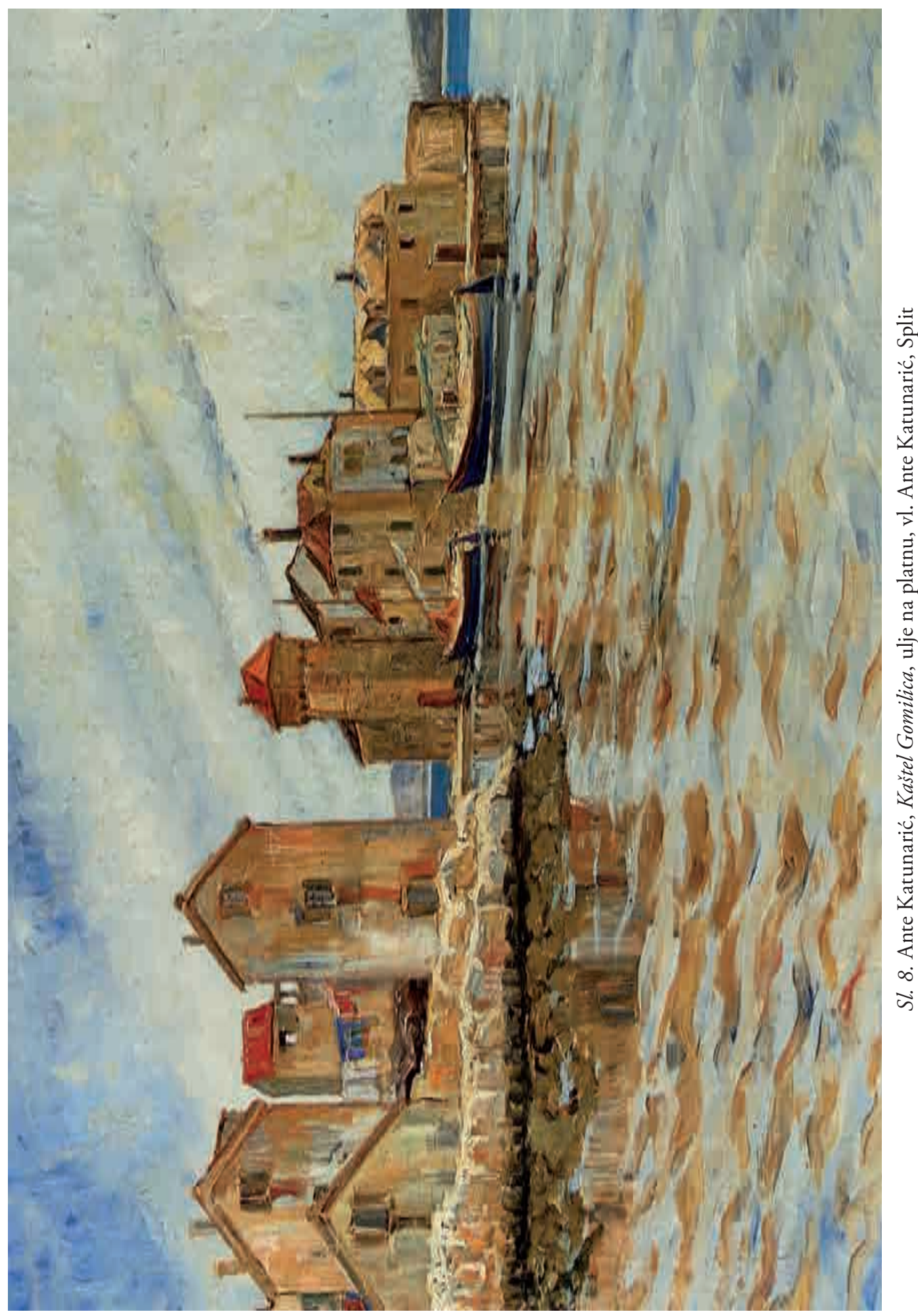




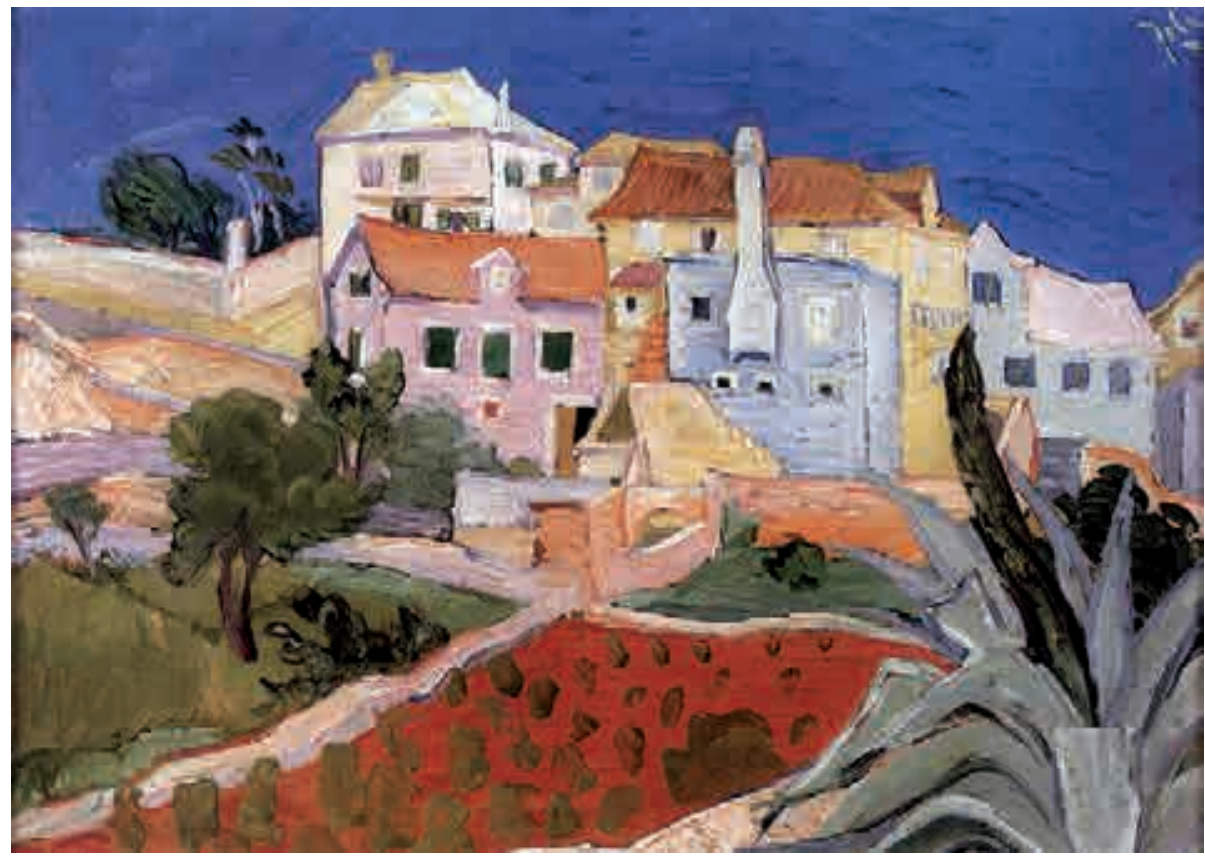

Sl. 9. Ignjat Job, Moj dom u Supetru (1929.), ulje na platnu, vl. Galerija umjetnina, Split

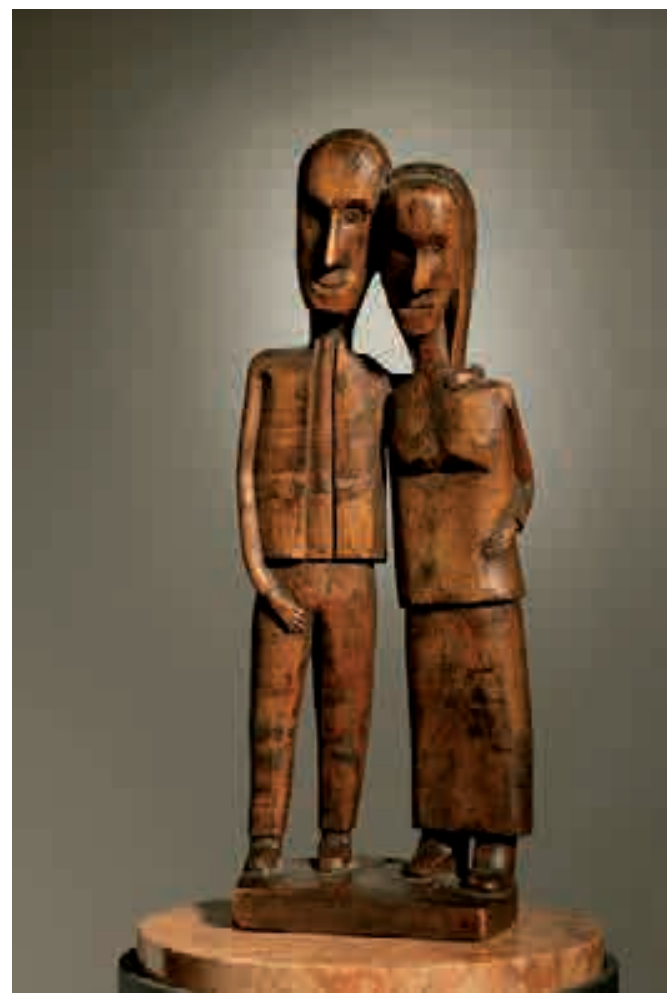

Sl. 10. Petar Smajić, Ljubavnici Adam i Eva (1936.), drvo, vl. Moderna galerija, Zagreb

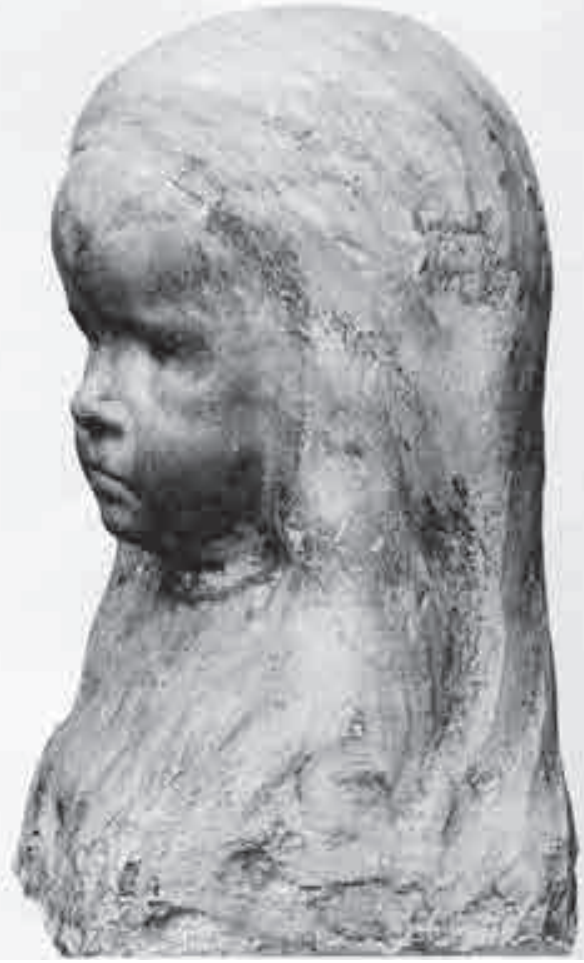

Sl. 11. Dujam Penić, Glava djevojčice (1910. 1912.), sadra, vl. Galerija umjetnina, Split 
Ovo je ono što se (...) javlja u primitivnoj umjetnosti svih naroda, a što je u posljednje vrijeme zainteresovalo moderni svijet, pa makar dolazilo to iz nutrine crnačke Afrike. To je ona kozmopolitska crta jednostavne duše, koja na svoj primitivan način traži izražaja. A Smajić je dijete jednog kraja, gdje su se vjekovima vitlale borbe i ukrštavanja, i gdje je ta kozmopolitska crta mogla da nađe i jačeg izražaja. ${ }^{53}$

Za kiparstvo Dujma Penića može se prihvatiti odrednica „realističkoga klasicizma“, nastaloga kao „odmjereni sklad realnog zapažanja i klasičnog osjećanja“. ${ }^{4}$ Potaknut i nadahnut upravo njegovom umjetnošću Vladan Desnica napisao je jednu od svojih rijetkih likovnih kritika, u kojoj snažno odjekuju duboko humanistički i vitalistički principi, odnosno poistovjećivanje umjetnosti i života. Ističe kako se u Penićevim radovima

(...) život očituje potkožan, tih ali topao, mirno i harmonično ritmiziran. U njima se naslućuju pod kožom optok krvi i mirni otkucaji srca (...) Veličina ljudskoga kod Penića se nikad ne potencira do nadčovjeka, do poluboga. I najveća emocija kod njega ostaje potpuno ljudska. Stoga je njegova umjetnost humana, prijemljiva, prisna. ${ }^{55}$

U Penićevim skulpturama Desnica pronalazi „intimni unutrašnji život“, „usklađeni pokret i euritmiju“, „živost i mirnu akciju“, „živi ritam“, „puls“ i „ljudski osjećaj”, ističući kako je „kroz liričnost svoga temperamenta Penić kadar da proćuti i izrazi i najveće, i najelementarnije emocije ljudskoga duha, i to u jednoj duboko humanoj formi“. Desnica uzima u obzir Penićevu zavičajnost, no dovodeći je u skladnu vezu sa životnim i likovnim principima, poput ritma, harmonije, na nju gleda kao na čvrstu vezu s kulturnom tradicijom:

U Penićevim odlikama: u euritmiji života, skladnosti i harmoničnosti koncepcija i staloženosti izraza, u njegovu stavu koji (...) je osjećajem protkana, sređena kontemplativnost, u tom dubokom i mirnom sisanju sokova života i u tom mirnom ali širokom zahvatu svih ljudskih elementarnih sadržaja i emocija, mi gledamo blagodat jednog kulturnog naslijeđa koje - više nego što bi nasljeđivalo po krvi - živi u duhovnoj atmosferi i u kulturnoj tradiciji, a kojoj je najjasniji znamen instinktivna, prirođena familijarnost sa višim stepenima razvoja čovječjeg duha i umjetničkog izražavanja. ${ }^{56}$

Budući da se izuzetno poetičnim, estetički duboko utemeljenim i promišljenim shvaćanjem i interpretacijom Penićeve umjetnosti Desnica ovim tekstom iskazao, nije pretjerano reći, kao jedan od najkvalitetnijih predstavnika splitske likovne kritike, nama povjesničarima umjetnosti je za žaliti, što se njome nije intenzivnije bavio.

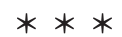

53 Vinko Brajević, „Izložba radova seljaka Petra Smajića“, Novo doba (Split), br. 48, 26. 2. 1934., 5.

54 Grgo Gamulin, Hrvatsko kiparstvo XIX. i XX. stoljeća, Zagreb 1999., 197.

55 Vladan DesnicA, „Kipar Dujam Penić“, Novo doba (Split), br. 241, 14. 10.1933., 9.

56 Isto. 
Nedovoljna istraženost pojedinih opusa protagonista splitske likovne scene onemogućava preciznu valorizaciju ne samo pojedinačnih doprinosa, nego i kvalitativne dosege čitave scene. U sjeni Meštrovićevih i Vidovićevih vrhunaca, u Splitu je stvaralo nekoliko zanimljivih umjetnika koje tek treba istražiti, a potom nova saznanja prezentirati na lokalnoj, ali i nacionalnoj razini te precizirati njihovo mjesto unutar nacionalnih povijesnih pregleda. $U$ prvoj polovici dvadeset i prvoga stoljeća, ovakvo istraživanje splitske likovne scene pokazalo bi mnogo slabiju antimodernističku komponentu te izrazitu prisutnost modernističkih, pa i postmodernističkih likovnih izraza.

\section{$\cos$ \\ The Interwar Art Scene in Split between Modernism And Anti-Modernism}

The paper examines the art scene in interwar Split. Along with the dominant moderate modernism, special attention is paid to the very pronounced anti-modernist tendency, which was an important feature of the broader art context in Europe and Croatia. Both the artists and art critics were almost united in their suspicion of avant-garde movements in art as well as in their preoccupation with regional themes, whereas modernism developed in Split in pronounced harmony with tradition. The art scene in Split grew after World War I, and as many as 130 exhibitions were mounted in the interwar period. It can be said that the Split artists active at the time worked in the shadow of their great and renowned contemporaries such as Ivan Meštrović, Marin Tartaglia, Jerolim Miše and Jozo Kljaković, who kept strong connections to Split although they did not reside in it then. Animosity to avant-garde movements is especially felt in the reception of the works of Marin Tartaglia, which were done in the manner of the Italian avant-garde and presented at the Medulić exhibition in 1919; they were characterized by critics as "perverted" and "disgusting." Ivo Dellale stands out among the art critics in Split; a pioneer in the appropriation of Croce's aesthetics in Croatia, he wrote about contemporary European art with considerably greater appreciation (especially cubism and expressionism). In the interwar painting in Split one recognizes anti-modernism in the work of Emanuel Vidović, which is greatly permeated by melancholy, nostalgia and the patina of time, in Ignjat Job's ecstatic scenes brimming with the dynamics of Mediterranean life, in Silvije Bonacci Čiko's paintings as metaphors of nostalgia and praises to the sea, in Vjekoslav Parać and Milan Tolićs escape into the idealized home region, and in the work of the Meneghellos. Achievements of great quality in the field of graphic design and caricature can be found in the work of Radovan Tommaseo, Ivo Tijardović and Angjeo Uvodić, done in the style of art déco. The sculptural part of the Split art scene is examined on the examples of recognition of the original primitivism of form in the work of Petar Smajić, and the sensibility for classical forms in the work of Dujam Penić, which has been described by Vladan Desnica in the most competent manner.

Key words: art modernism in Split, anti-modernism, art criticism, painting, graphic design, caricature, sculpture, Vladan Desnica 


\section{es}

\section{Literatura}

Niko Bartulović, „Sa otvorenja Jobove izložbe“, Novo doba (Split), br. 162, 1. 7. 1929.

Nevenka Bezıć, Likovne izložbe Splita 1885-1945, Split 1962.

Silvije Bonacci Čıко, Katalog III. Kolektivne izložbe slikara Čika (S. Bonacci), Split 1928., 5-6.

Vinko Brajević, „Izložba radova seljaka Petra Smajića“, Novo doba (Split), br. 48, 26. 2. 1934., 5.

Miljenko Bukarica, „Umjetnici našega vremena“, Hrvatska riječ (Split), br. 139, 4. 10. 1924., 5-6.

Sandi Bulimbašıć, Društvo hrvatskih umjetnika „Medulić“, doktorska disertacija, Filozofski fakultet u Zagrebu, 2014.

Ćiro Čıčın ŠAIn, „Dalmatinski slikar koji je napustio Pariz da se vrati u Dalmaciju“, Novo doba (Split), br. 82, 7. 4. 1934., 9-10.

[Ćiro] Č[ičin] Š[AIN], „Pred posmrtnu izložbu Ignjata Joba“, Novo doba (Split), br. 156, 8. 7. 1937., 5.

Ćiro ČIČin ŠAIN, „Slikar Parać“, Novo doba (Split), br. 236, 26. 9. 1929., 5-6.

Ivo Delalle, „Benedetto Croce“, Hrvatska prosvjeta, 5/1918., br. 2, 13-16.

[Ivo] D[elalle], „Čiko“, Novo doba (Split), br. 220, 21. 9. 1924., 2-3.

Ivo Delalle, „Jerolim Miše“, Novo doba (Split), br. 144, 23. 6. 1923., 2-3.

Ivo Delalle, „Slike Meneghello-Dinčića“, Novo doba (Split), br. 231, 6. 10. 1923., 2.

Ivo Delalle, „Umjetnici s mora“, Jadran (Split), br. 52, 12. 4. 1919., 2.

Vladan Desnica, „Kipar Dujam Penić“, Novo doba (Split), br. 241, 14. 10. 1933., 9.

Frano Dulibić, Povijest karikature u Hrvatskoj do 1940. godine, Zagreb 2009.

Grgo Gamulin, Hrvatsko kiparstvo XIX. i XX. stoljeća, Zagreb 1999.

Katarina Hraste, „Benedetto Croce, mi i drugi“, Mogućnosti, 48/2001., br. 4-6, 25-45.

Juraj Ivanko, „Slikar Vjekoslav Parač“, Jadranski dnevnik (Split), br. 19, 12. 4. 1934., 3.

Lada Kavurić, Hrvatski plakat do 1940., Zagreb 1999.

Duško KečKemet, Likovna umjetnost u Splitu 1900 -1940., Split 2011.

Duško KečKemet, Nepoznati Tijardović, Split 2012.

Vinko Kisıć, „S umjetničke izložbe“, Novo doba (Split), br. 80, 12. 4. 1919., 2.

Zoran Kravar, Antimodernizam, Zagreb 2003.

Zoran Kravar, Svjetonazorski separei, Zagreb 2005.

Zoran Kravar, „Vidovdanski protusvjetovi i Matoševi protutekstovi“, 15 dana, 47/2004., br. 4-5, 8-15.

Ivo Lahman, „Izložba Vjekoslava Parača“, Novo doba (Split), br. 242, 3. 10. 1929., 5-6.

Ivo Lahman, „Ljetna izložba Ignjata Joba“, Novo doba (Split), br. 163, 2. 7. 1929., 2 i 7.

Slavica Marković (ur.), Stoljeće hrvatskog plakata, Zagreb 2001.

Momčilo Popadić, „Devedeset godina? Kad prije“, Slobodna Dalmacija (Split), 13738, 26. 2. 1989., 14-15.

Zlatko Posavac, „Rana recepcija estetike Benedetta Crocea u Hrvatskoj“, Filozofska istraživanja, 13/1993., br. 3, 675-684.

Branislav RAdicA, „Slikarstvo i priroda“, Hrvatska riječ (Split), br. 139, 4. 10. 1924., 6.

Ivanka ReBerski, Realizmi dvadesetih godina i hrvatsko slikarstvo, Zagreb 1994.

Vladimir Rismondo, „Izložba Vjekoslava Paraća“, Novo doba (Split), br. 301, 25. 12. 1936., 33. 
Iris Slade, Angjeo Uvodić, Split 2002.

Iris SLade, Ivan Mirković, Split 2005.

Vinko SRHoJ, „Stagnantni okvir zavičajnosti“, Slobodna Dalmacija (Split), br. 14449, 23. 2. 1991., 48-49.

Nedjeljko SuвотіĆ, „Jugoslavenska umjetnička izložba u Splitu“, Hrvatska prosvjeta, 6/1919., br. 5-6, 122-124.

S. V., „Sutra se kod Galića otvara izložba skulptora seljaka“, Novo doba (Split), br. 46, 23. 2. 1934., 5. Pero ŠEgotA, „Jedan posjet Čikinom atelijeru“, Novo doba (Split), br. 273, 23. 11. 1927., 2 i 7.

Ana ŠEPARović - Frano Dulibić, „Nekoliko primjera antimodernizma u hrvatskoj likovnoj umjetnosti“, Radovi instituta za povijest umjetnosti, 37/2013., 199-210.

Marin TARTAglia, „Vademecum posjetiocima izložbe. Umjetnosti veliki zabavljaču“, Jadran (Split), br. 49, 9. 4. 1919., 2.

Ivo Tijardović, „Sjećanje na život i vrijeme (6)“, Nedjeljna Dalmacija (Split), br. 652, 6. 11. 1983., 25.

Tin Ujević, „Dvije izložbe“, Jadranska pošta (Split), br. 110, 13. 5. 1930., 6-7.

Tin Ujević, Rosandić, Zagreb 1920.

Tin UJević, „Umjetnički Split. Šef ukusa Galić“, Jadranska pošta (Split), br. 107, 9. 5. 1930., 6-7. Igor Zidić, Emanuel Vidović, Rovinj 2002.

Igor Zidić, Vjekoslav Parać, Zagreb 2010.

\section{Neobjavljeni izvori}

Vjekoslav Parać - Vladanu Desnici, Pariz, 30. ožujka 1931., Osobna ostavština Vladana Desnice, kut. Prepiska do 1945. I. 